\title{
Alcohol-containing Hand Rubs: A Survey on Beliefs and Self-reported Practices of Muslim Nurses
}

\author{
Mehrdad Askarian \\ https://orcid.org/0000-0003-4163-7414 \\ Shiraz University of Medical Sciences \\ askariam@sums.ac.ir

\section{Yves Longtin} \\ https://orcid.org/0000-0002-4532-379X \\ McGill University \\ yves.longtin@mcgill.ca
}

\author{
Ramin Shiraly \\ https://orcid.org/0000-0002-7429-0106 \\ Shiraz University of Medical Sciences \\ shiralyr@sums.ac.ir \\ Seyed Sadeq Seyed Nematian \\ https://orcid.org/0000-0002-1084-8086 \\ Shiraz University of Medical Sciences \\ s_nematian@sums.ac.ir
}

\section{Abstract}

Although alcohol-containing liquid cleansers have been increasingly used by healthcare workers, their application is still suboptimal. This study was carried out to assess the beliefs and practices of Muslim nurses with respect to alcoholbased hand rub solutions (ABHRs). A total of 374 hospital nurses from a large tertiary referral medical centre in Southern Iran were recruited. Beliefs and selfreported practices toward ABHRs were measured using a structured questionnaire. The validity and reliability of the questionnaire were shown to be satisfactory (Cronbach's alpha value: 0.77 for beliefs and 0.86 for practices.) Overall, $16 \%$ of Muslim nurses believed that the use of ABHRs is religiously prohibited; approximately the same proportion of respondents believed that there may be concerns related to the fact that the alcoholic content of these hand rubs might be absorbed through the skin or respiratory tract. Overall, more than half of participants reported use of ABHRs before $(60 \%)$ and after $(75 \%)$ touching patients. Religious believers were less likely to report performing hand hygiene with ABHRs before patient contact. However, the total mean practice scores were not statistically different between religious believers and nonbelievers ( $\mathrm{t}(372)=-0.88, \mathrm{P}=0.413)$. Mean practice scores of nurses who had participated in hand hygiene training courses during the year before the study were higher than those who had not $(\mathrm{t}(372)=3.41, \mathrm{P}<0.001)$. The results of the present study showed that the practice of hand hygiene with alcohol-containing

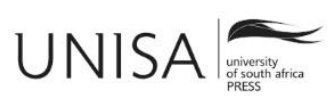


Askarian, Shiraly, Longtin, Seyed Nematian

hand rubs is common among Iranian Muslim nurses and is not influenced by their religious beliefs toward alcohol.

Keywords: hand hygiene; alcohol-based hand rubs; Muslim; practice; religion

\section{Introduction}

Healthcare-associated infections are a serious problem in hospitals worldwide and affect $5 \%$ of hospitalised patients, which are mostly spread via healthcare workers' hands. Hence, hand hygiene is one of the most effective ways to reduce nosocomial infections (Chavali, Menon, and Shukla 2014). Hand washing with soap and water is the most common hand cleansing method in hospitals, but in recent decades, the use of alcoholbased hand rub solutions (ABHRs) has become more popular amongst healthcare workers (Bessonneau, Clément, and Thomas 2010). Microbiologic studies have shown that ABHRs are more effective than the combination of soap and water for removing microorganisms from the hands (Bessonneau et al. 2010; Picheansathian 2004). The antimicrobial properties of alcohol are well established and include bactericidal, virucidal, mycobactericidal and fungicidal activities. In contrast to antiseptic soaps, ABHRs do not require a basin or water supply, and are less time consuming than hand washing (Bessonneau et al. 2010; Picheansathian 2004). According to studies, hand disinfection with ABHRs is considered a simple way to reduce nosocomial infections as well as being the most cost-effective (Girou et al. 2002; Von Lengerke 2017). Hand rubbing with alcohol-based solutions increases compliance with hand hygiene and is associated with a greater reduction in bacterial contamination of hands than conventional hand washing with soaps/detergents (Ahmed et al. 2006).

Cultural and religious beliefs can potentially affect hand hygiene practices (Allegranzi et al. 2009). Deep-seated beliefs in some communities might influence healthcare workers' attitudes towards hand cleansing during healthcare delivery. For instance, Judaism, Islam and Sikhism have specific rules for hand washing before religious practices, and therefore a believer is careful of any ramifications according to religious principles in everyday life (Pittet 2009).

Islamic rules strictly prohibit the consumption of any alcoholic beverages; it is believed that drinking alcohol can cause disconnection from a state of spiritual awareness or consciousness. However, there are different opinions regarding contact with materials likely to contain alcohol such as perfumes or antiseptics. According to Islamic rules, any material, such as alcohol, which is religiously prohibited is called "Najis" and should be avoided; however, the use of alcohol as a medical agent is authorised (Longtin et al. 2011; Michalak, Trocki, and Katz 2009). While many Muslims believe that the prohibition of alcohol does not apply to the use of perfumes or antiseptics with an alcoholic content, some believe that any exposure to alcohol is strictly forbidden $(\mathrm{Ng}$, Shaban, and Van de Mortel 2019). 
Although ABHRs are highly efficacious in preventing healthcare-associated infections, healthcare professionals' compliance is sub-optimal (Kingston, O'Connell, and Dunne 2018). Initiatives to improve hand hygiene compliance clearly must address different factors, including sociocultural and religious issues (Borg et al. 2009). This study aimed to assess whether religious beliefs play a role in Muslim nurses' choice to use ABHRs as a hand disinfectant.

\section{Methods}

\section{Study Setting}

The study setting was a university hospital in Shiraz city in Fars Province. Shiraz is the largest metropolis in Southern Iran and has a population of approximately 2 million in an area of $240 \mathrm{~km}^{2}$. Namazi hospital is a 1200 -bed tertiary care centre affiliated with Shiraz University of Medical Sciences. It is the largest general public hospital in Southern Iran serving the town, surrounding townships and provinces. It provides diverse services for patients from different parts of the country. The hospital includes outpatient and inpatient services and 24-hour emergency wards, as well as 10 ICUs and many general, specialty and subspecialty wards.

\section{Study Design}

This was a cross-sectional study, conducted from December 2017 to January 2018, aimed to assess Iranian Muslim nurses' beliefs and self-reported practices with regard to alcohol-based hand rubs. A structured face-to-face interview approach was chosen to enable participants to express their beliefs and to report their practices. As a result, data were obtained by a self-reported questionnaire.

\section{Participants}

We selected our target sample from Muslim nurses with a minimal work experience of one year, who directly give care to hospitalised patients. There were more than 1000 currently practising nurses in Namazi hospital. The selected nurses were invited to participate in the study, were informed about the study aims and were ensured of data confidentiality.

\section{Sample Size}

The required sample size was calculated using a single population proportion formula, with the assumption that $50 \%$ of nurses practise hand hygiene with alcoholic hand rubs regardless of their religious views, and a $95 \% \mathrm{CI}$ and $4 \%$ margin of error. We estimated that there were 800 eligible nurses for the study. Considering a non-response rate of $10 \%$, the final minimum sample size was 370 nurses. Inclusion criteria included nurses who were Muslim, practising as a nurse for at least one year, and regularly provided direct care to patients for more than 30 hours a week on an in-patient ward. A total of 374 eligible participants were randomly selected (using a table of random digits) from 
Askarian, Shiraly, Longtin, Seyed Nematian

the list of working nurses in the hospital (with a nursing diploma degree or higher) obtained from the hospital nursing office.

\section{Instruments and Data Collection}

The data were collected via a purpose-designed, structured questionnaire to assess nurses' religious beliefs and practices with regard to ABHRs. The questionnaires were delivered in person by research staff, and the nurses completed the questionnaires anonymously and returned them on the same day. The questionnaire included the following sections:

1. Demographic information included age, gender, educational levels and work experience and a question about their participation in hand hygiene training courses during the past year.

2. Seven questions about the nurses' religious beliefs and perceptions regarding ABHRs. The nurses could respond as "Agree" or "Don't agree."

3. Five questions about the nurses' practice of ABHRs.

Practice questions were rated on the Likert scale (always, most of the time, occasionally, rarely and never). The total scores ranged between 5 and 25 . Practice scores were compared between religious believers and non-believers.

The questionnaire was designed by an expert in hospital infection control and the content and face validity of the questionnaire were confirmed by two other specialists in the field of epidemiology and infectious diseases. The reliability of the questionnaire was calculated after a pilot study and the Cronbach's alpha value was found to be 0.77 for beliefs and perceptions and 0.86 for practices.

\section{Statistical Analysis}

The data were analysed using SPSS statistical software, version 19 (IBM, United States). Demographic factors were described as frequency and percentage for categorical variables and mean and standard deviation for numerical variables. The mean and standard deviation of the practice scores were calculated and the differences between the two groups were tested using an independent t-test. With regard to the use of ABHRs in different patient care situations, we considered "always" or "most of the time" responses as high frequency use and "occasionally, rarely and never" responses as low frequency use of ABHRs. A Chi square test was used to compare that behaviour between believers and non-believers. The significance level was considered 0.05 for all statistical analyses.

\section{Ethical Approval}

This project received ethical approval from the Research Ethics Committee of Shiraz University of Medical Sciences. Written, informed consent was obtained from all participants. 


\section{Results}

A total of 374 nurses participated in the study, with a response rate of $100 \%$. The mean age of participants was $29.9( \pm 6.1)$ years (range $21-59)$ with a mean work experience of $5.5( \pm 4.8)$ years (range 1-27). Most participants (82.7\%) were female, 93.3\% had a bachelor or master's degree, $67.6 \%$ were working in medical wards, and $52.9 \%$ had participated in hand hygiene training courses during the past year (table 1).

Table 1: Main characteristics of the study population

\begin{tabular}{|l|l|l|}
\hline Variable & Staff nurses (N=374) \\
\hline \multirow{2}{*}{ Age (yrs) } & Mean & $\mathbf{\text { SD }}$ \\
\cline { 2 - 3 } & 30 & 6.1 \\
\hline Work experience (yrs) & 5.5 & 4.8 \\
\hline & Number & $\%$ \\
\hline Gender & & \\
\hline Female & 309 & $82.7 \%$ \\
\hline Male & 65 & $17.3 \%$ \\
\hline Educational level & & \\
\hline A nursing diploma & 25 & $6.7 \%$ \\
\hline A bachelor or master's degree & 349 & $93.3 \%$ \\
\hline Hospital wards & & \\
\hline Surgical & 121 & $32.4 \%$ \\
\hline Medical & 253 & $67.6 \%$ \\
\hline Attending in hand hygiene training class & & \\
\hline Yes & 198 & $52.9 \%$ \\
\hline No & 176 & $47.1 \%$ \\
\hline
\end{tabular}

Sixteen per cent of nurses believed that the use of ABHRs is religiously prohibited; approximately the same proportion of respondents believed that there may be religious concerns related to the fact that the alcoholic content of these hand rubs might be absorbed through the skin (14.7\%) or through the respiratory tract (15.8\%).

At the same time, more than $80 \%$ of nurses thought that the use of ABHRs is an easy and fast way for hand disinfection. More than half of the participants agreed that ABHRs 
are more effective than water and soap for hand hygiene. Nonetheless, about one third of nurses were worried about skin irritation side effects (table 2).

Regarding practice, more than $60 \%$ of nurses reported using ABHRs before touching patients, and $75 \%$ used them after touching patients always or most of the time. High frequency use of ABHRs was common among nurses who were religious believers, so that more than half of them reported application of ABHRs during patient care always or most of the time. The most common situation in which ABHRs were used was after doing a clean/aseptic procedure (84.2\%). Believers were less likely to report performing hand hygiene before patient contact, compared with non-believers (OR: 1.83, CI 95\%:1.05-3.20, P =0.040) (table 3).

Table 4 shows the mean and standard deviation of practice scores of participants according to the study variables. The mean of practice scores of all of the participants was $20.15 \pm 3.53$.

The mean practice scores were not statistically different between subgroups including religious believers and non-believers ( $(\mathrm{df})$ : -0.88 (372), $\mathrm{P}=0.378$ ). Mean practice scores of nurses who had participated in hand hygiene training courses were higher than those who had not (t (df): -3.41 (372), $\mathrm{P}<0.001)$.

Table 2: Muslim nurses' perceptions and religious beliefs regarding application of alcohol-based hand rub solutions (ABHRs) for hand disinfection during patient care

\begin{tabular}{|l|l|l|l|l|}
\hline \multirow{2}{*}{ Beliefs and perceptions regarding ABHRs } & \multicolumn{2}{|l|}{ Agree } & \multicolumn{2}{l|}{ Don't agree } \\
\cline { 2 - 5 } & Number & $\mathbf{\%}$ & Number & $\mathbf{\%}$ \\
\hline Use of ABHRs is religiously prohibited & 60 & $16 \%$ & 314 & $84 \%$ \\
\hline $\begin{array}{l}\text { I am concerned that alcoholic content of ABHRs } \\
\text { might be absorbed through the skin }\end{array}$ & 55 & $14.7 \%$ & 319 & $85.3 \%$ \\
\hline $\begin{array}{l}\text { I am concerned that ABHRs might be absorbed } \\
\text { through the respiratory tract }\end{array}$ & 59 & $15.8 \%$ & 315 & $84.2 \%$ \\
\hline Use of ABHRs is an easy way to disinfect hands & 327 & $87.4 \%$ & 47 & $12.6 \%$ \\
\hline $\begin{array}{l}\text { ABHRs are more effective than water and soap } \\
\text { for hand disinfection }\end{array}$ & 198 & $52.9 \%$ & 176 & $47.1 \%$ \\
\hline $\begin{array}{l}\text { ABHRs are less harmful to skin compared to } \\
\text { water and soap }\end{array}$ & 216 & $57.8 \%$ & 158 & $42.2 \%$ \\
\hline $\begin{array}{l}\text { ABHRs hurt hands and I am concerned about } \\
\text { adverse skin irritation }\end{array}$ & 118 & $31.6 \%$ & 256 & $68.4 \%$ \\
\cline { 2 - 5 } & & & & \\
\hline
\end{tabular}


Askarian, Shiraly, Longtin, Seyed Nematian

Table 3: Comparison of frequency use of alcohol-based hand rub solutions (ABHRs) between religious believers and non-believers

\begin{tabular}{|c|c|c|c|c|c|}
\hline \multicolumn{2}{|c|}{$\begin{array}{l}\text { Frequency of use of alcohol- } \\
\text { based hand rubs during } \\
\text { different patient care } \\
\text { situations }\end{array}$} & \multirow{2}{*}{$\begin{array}{l}\text { Believers** } \\
\text { Number } \\
(\%) \\
31(51.7)\end{array}$} & \multirow{2}{*}{$\begin{array}{l}\text { Non- } \\
\text { believers } \\
\text { Number } \\
(\%) \\
208(66.2)\end{array}$} & \multirow{3}{*}{$\begin{array}{l}\text { OR }(\text { CI 95\%) } \\
1.83(1.05-3.20)\end{array}$} & \multirow{3}{*}{$\begin{array}{l}\text { P value } \\
0.040 * * *\end{array}$} \\
\hline \multirow[t]{2}{*}{$\begin{array}{l}\text { Before touching } \\
\text { patients }\end{array}$} & $\begin{array}{l}\text { High } \\
\text { frequency* }\end{array}$ & & & & \\
\hline & $\begin{array}{l}\text { Low } \\
\text { frequency }\end{array}$ & $29(48.3)$ & $106(33.8)$ & & \\
\hline \multirow{2}{*}{$\begin{array}{l}\text { After procedures } \\
\text { with potential } \\
\text { exposure to blood } \\
\text { and secretions }\end{array}$} & $\begin{array}{l}\text { High } \\
\text { frequency }\end{array}$ & 37 (61.7) & $211(67.2)$ & \multirow[t]{2}{*}{$1.27(0.71-2.25)$} & \multirow[t]{2}{*}{0.456} \\
\hline & $\begin{array}{l}\text { Low } \\
\text { frequency }\end{array}$ & $23(38.3)$ & $103(32.8)$ & & \\
\hline \multirow[t]{2}{*}{$\begin{array}{l}\text { After touching } \\
\text { patients }\end{array}$} & $\begin{array}{l}\text { High } \\
\text { frequency }\end{array}$ & $43(71.7)$ & 243 (77.4) & \multirow[t]{2}{*}{$1.35(0.72-2.51)$} & \multirow[t]{2}{*}{0.325} \\
\hline & $\begin{array}{l}\text { Low } \\
\text { frequency }\end{array}$ & $17(28.3)$ & $71(22.6)$ & & \\
\hline \multirow{2}{*}{$\begin{array}{l}\text { After doing a } \\
\text { clean/aseptic } \\
\text { procedure }\end{array}$} & $\begin{array}{l}\text { High } \\
\text { frequency }\end{array}$ & $45(75)$ & $270(86)$ & \multirow[t]{2}{*}{$2.04(1.05-3.98)$} & \multirow[t]{2}{*}{0.051} \\
\hline & $\begin{array}{l}\text { Low } \\
\text { frequency }\end{array}$ & $15(25)$ & $44(14)$ & & \\
\hline \multirow{2}{*}{$\begin{array}{l}\text { After touching a } \\
\text { patient's bed } \\
\text { sheet/bed }\end{array}$} & $\begin{array}{l}\text { High } \\
\text { frequency }\end{array}$ & $45(75)$ & 268 (85.4) & \multirow[t]{2}{*}{$1.94(1.00-3.76)$} & \multirow[t]{2}{*}{0.056} \\
\hline & $\begin{array}{l}\text { Low } \\
\text { frequency }\end{array}$ & $15(25)$ & $46(14.6)$ & & \\
\hline
\end{tabular}

*High vs. Low frequency use: using ABHRs “always, most times" vs. “occasionally, rarely and never"

**Nurses who believed that alcohol-based hand rubs are religiously prohibited *** Significance level: 0.05 
Askarian, Shiraly, Longtin, Seyed Nematian

Table 4: Practice scores of Muslim nurses ( $n=374)$ regarding use of alcohol-based hand rubs based on demographic and other associated variables

\begin{tabular}{|l|l|l|l|l|}
\hline Characteristics & $\begin{array}{l}\text { Mean practice } \\
\text { score }\end{array}$ & $\begin{array}{l}\text { Standard } \\
\text { deviation }\end{array}$ & $\begin{array}{l}\text { t statistics } \\
\text { (df: 372) }\end{array}$ & P value** $^{* *}$ \\
\hline Gender & & & & \\
\hline Female & 20.24 & 3.61 & 0.62 & 0.372 \\
\hline Male & 19.93 & 3.21 & & \\
\hline Age & & & & \\
\hline$<28$ & 20.70 & 3.32 & -1.03 & 0.305 \\
\hline$\geq 28$ & 20.44 & 3.21 & & \\
\hline Educational level & & & & \\
\hline $\begin{array}{l}\text { A bachelor or master's } \\
\text { degree }\end{array}$ & 20.38 & 3.51 & -0.28 & 0.781 \\
\hline A nursing diploma & 20.61 & 3.28 & & \\
\hline Work experience & & & & \\
\hline$<5$ years & 20.32 & 3.44 & -0.31 & 0.759 \\
\hline$\geq 5$ years & 20.44 & 3.05 & & \\
\hline Ward & & & & \\
\hline Surgical & 20.10 & 3.63 & -0.17 & 0.863 \\
\hline Medical & 20.17 & 3.47 & & \\
\hline $\begin{array}{l}\text { Hand hygiene training } \\
\text { course in the past year }\end{array}$ & & & & \\
\hline Yes & 20.73 & 3.36 & -3.41 & $<0.001$ \\
\hline No & 19.50 & 3.61 & & \\
\hline Religious belief & & & & \\
\hline Believers & 19.78 & 3.84 & -0.88 & 0.378 \\
\hline Non-believers & 20.22 & 3.47 & & \\
\hline
\end{tabular}

* Nurses who believed that use of alcohol-based hand rubs is religiously prohibited

** Significance level: 0.05

\section{Discussion}

Hand hygiene practice, as a health-related behaviour, might be of multifactorial origin. It has been stated that cultural and religious beliefs can significantly influence the hand hygiene behaviour of healthcare workers (Allegranzi et al. 2009). Numerous studies have investigated barriers to hand hygiene and interventions to improve compliance (Doronia et al. 2017; Erasmus et al. 2010; Sands and Aunger 2020), yet few studies have considered religious beliefs as an influencing factor on nurses' behaviour regarding alcohol-based hand rubs (Borg et al. 2009) 
According to the results of our study, only a minority of Muslim nurses thought that the use of alcohol-based hand rubs is religiously forbidden, and interestingly, more than half of the believers used alcohol-based hand rubs always or most of the time during their practice. There seems to be a discrepancy between what they believe and what they do. Maybe some nurses do not take religious beliefs into account when they are caring for patients because they think their beliefs might impact the quality of care negatively. Another possible reason is that they might be in doubt whether this religious prohibition on alcohol would be applicable to alcohol-based hand rubs. Even though believers did not differ from non-believers in terms of hand hygiene practice score, believers were significantly less likely to report the application of ABHRs before patient contact. Clarification of this discrepancy necessitates further study.

There are few studies that have investigated Muslim nurses' behaviour with regard to ABHRs. A study of healthcare workers in the Saudi Arabian National Guard Health Affairs Hospitals showed that there was no difficulty or reluctance for the use of ABHRs, but the authors declared that most of the participants were expatriates, often non-Muslim or highly selected professionals with Western training (Ahmed et al. 2006). In a study conducted in Jordan, most Muslim nurses showed a positive attitude towards hand hygiene, but their compliance with respect to religious issues was not reported as a studied variable (Darawad et al. 2012).

The findings of the present study also showed that $14.7 \%$ and $15.8 \%$ of nurses were worried about cutaneous and respiratory absorption of the alcohol into their body, respectively, and so they believed that it is forbidden by their religion. It had been previously reported that some Muslim healthcare workers were concerned about potential cutaneous or respiratory exposure to alcohol when using ABHRs (Ahmed et al. 2006). During hand disinfection with ABHRs, alcohol might be absorbed via skin or lungs, but it has been shown that even after long-term exposure, the amount of absorbed ethanol is negligible (Below et al. 2012; Brown et al. 2007; Gessner et al. 2016). Hence, alcohol-based hand rubs are safe but for some Muslim nurses, their negligible absorption may be a matter of concern.

Amongst our study population, about one third of nurses were concerned about adverse skin irritation side effects of alcohol-based hand rubs. This finding was in line with many other studies in which a commonly reported side effect of ABHRs was skin dryness and irritation (Assefa et al. 2021; Kampf and Löffler 2007; Sharma et al. 2015; Takra, Gutkowska, and Nitsch-Osuch 2019). Skin irritation and contact dermatitis with ABHRs were specially reported in people with an aldehyde dehydrogenase deficiency (Lachenmeier 2008). In a study in China among healthcare workers, skin irritation was one of the most common barriers to use ABHRs (Li et al. 2015). Also, a study within a large teaching hospital in Ireland showed that the major barriers to using ABHRs by nurses were skin sensitivity and irritation (Kingston et al. 2017). Regardless of religious beliefs, the fear of skin damage from ABHRs is a common misconception. It must be noted that ABHRs cause less dermatitis than soap and water if used at the same 
frequency. ABHRs contain emollients that will protect the skin from irritation, whereas soap and water remove lipids from the skin surface, causing drying and dermatitis (Kampf and Kramer 2004; Picheansathian et al. 2004).

The frequency of use of ABHRs varies substantially among nurses under different situations; with the greatest frequency recorded from intensive care units (Boyce et al. 2017). Our findings showed that the highest frequencies of self-reported usage of ABHRs by Muslim nurses were after touching patients and after performing clean/aseptic procedures, and the lowest frequency was before touching patients. There was no significant difference between the frequency of the use of ABHRs in medical and surgical wards. An observational study in a surgical ICU ward in India found that nurses' compliance with hand hygiene was lowest (39\%) before aseptic procedures and highest (93\%) after touching a patient, and the overall compliance was $63 \%$ (Chavali et al. 2014). In another study from Ethiopia, overall compliance was $18.7 \%$, the highest before cleaning or aseptic procedures. In this study, using ABHRs was the most common method of hand disinfection (Awoke et al. 2018).

A study on Irish nursing students' attitude towards hand hygiene found highly positive attitudes, but only $22 \%$ of them reported routine use of ABHRs, and hand hygiene compliance was the highest after exposure to body fluids and lowest after touching patients' bed sheets (Kingston et al. 2018).

Finally, the results of the present study indicated that hand hygiene training courses might have a positive impact on nurses' practice with regard to ABHRs. Many studies have demonstrated a positive association between hand hygiene training and health workers' compliance (Alshehari, Park, and Rashid 2018) and it seems that this is also true for alcohol-based hand rubs.

WHO has launched different strategies and published guidelines to improve hand hygiene practices around the world. Although most countries are following the recommended guidelines to improve hand hygiene practices, self-reported hand hygiene compliance among healthcare workers was suboptimal and lowest before touching patients ( $\mathrm{Li}$ et al. 2015; Reichardt et al. 2013). Even in high income countries, average compliance was reported in 2010 to be about 40\% (Erasmus et al. 2010). To improve hand hygiene compliance, multifaceted approaches including education, reminders and continuous performance feedback are more effective than a single type intervention. Also, the impact of religious beliefs has been emphasised by the WHO to be taken into consideration (Randle et al. 2014; World Health Organisation 2009).

\section{Limitations}

There are some limitations to our study. This was a single-centre cross-sectional study; therefore, it is difficult to generalise the results to all Iranian Muslim nurses. However, the study setting was the main referral centre in Fars (the largest province of Southern Iran with 5 million inhabitants) with more than 1000 practising nurses. We assessed 
self-reported practices of nurses with regard to hand hygiene, which is less accurate than direct observation of behaviours. Nevertheless, the self-report is a widely used method that could be relied upon as an alternative choice to assess an extensive range of health behaviours, particularly when there is no stigma associated with those specific behaviours.

\section{Conclusions}

Alcohol-containing hand rubs are commonly used by Iranian Muslim nurses so that more than half of them utilise ABHRs in different patient care situations. The results of the present study showed that the practice of hand hygiene with alcohol-containing hand rubs among Iranian Muslim nurses is not influenced by their religious beliefs toward alcohol.

For those who were reluctant to use ABHRs, skin dryness and irritation were the biggest concern. Periodic refresher training courses should be scheduled, where the safety of ABHRs should be emphasised.

\section{Contributions, Competing Interests and Ethical Clearance}

All authors have equally contributed to the design of the study, acquisition of data, analysis, and interpretation of results and have read and approved the final manuscript. No competing interests are declared. The study was approved by the Research Ethics Committee of Shiraz University of Medical Sciences.

\section{Acknowledgements}

The Vice Chancellor for Research at Shiraz University of Medical Sciences funded this project. This research was performed by Dr Seyed Nematian in partial fulfilment of the requirements for certification as a specialist in community medicine at Shiraz University of Medical Sciences in Shiraz, Iran (No. 94-9720). The authors wish to thank $\mathrm{Mr} \mathrm{H}$. Argasi for his invaluable assistance in editing this manuscript.

\section{References}

Ahmed, Q. A., Z. A. Memish, B. Allegranzi, and D. Pittet. 2006. "WHO Global Patient Safety Challenge. Muslim Health-care Workers and Alcohol-based Hand Rubs." Lancet 367 (9515): 1025-7. https://doi.org/10.1016/S0140-6736(06)68431-6.

Allegranzi, B., Z. A. Memish, L. Donaldson, and D. Pittet. 2009. "Religion and Culture: Potential Undercurrents Influencing Hand Hygiene Promotion in Health Care." American Journal of Infection Control 37: 28-34. https://doi.org/10.1016/j.ajic.2008.01.014

Alshehari, A. A., S. Park, and H. Rashid. 2018. "Strategies to Improve Hand Hygiene Compliance among Healthcare Workers in Adult Intensive Care Units: A Mini Systematic Review." Journal of Hospital Infection 100 (2): 152-158. https://doi.org/10.1016/j.jhin.2018.03.013. 
Assefa, D., T. Melaku, B. Bayisa, and S. Alemu. 2021. "Knowledge, Attitude and SelfReported Performance and Challenges of Hand Hygiene Using Alcohol-Based Hand Sanitizers among Healthcare Workers during Covid-19 Pandemic at a Tertiary Hospital: A Cross-Sectional Study." Infection and Drug Resistance 14: 303-313. https://doi.org/10.2147/IDR.S291690.

Awoke, N., B. Geda, A. Arba, T. Tekalign, and K. Paulos. 2018. "Nurses Practice of Hand Hygiene in Hiwot Fana Specialized University Hospital, Harari Regional State, Eastern Ethiopia: Observational Study." Nursing Research and Practice 2018: 2654947. https://doi.org/10.1155/2018/2654947.

Below, H., I. Partecke, N. O. Huebner, N. Bieber, T. Nicolai, A. Usche, O. Assadian, E. Below, G. Kampf, W. Parzefall, C. D. Heidecke, D. Zuba, V. Bessonneau, T. Kohlmann, and A. Kramer. 2012. "Dermal and Pulmonary Absorption of Propan-1-ol and Propan-2-ol from Hand Rubs." American Journal of Infection Control 40 (3): 250-7. https://doi.org/10.1016/j.ajic.2011.03.009.

Bessonneau, V., M. Clément, and O. Thomas. 2010. "Can Intensive Use of Alcohol-Based Hand Rubs Lead to Passive Alcoholization?” International Journal of Environmental Research and Public Health 7 (8): 3038-3050. https://doi.org/10.3390/ijerph7083038.

Borg, M. A., M. Benbachir, B. D. Cookson, S. Ben Redjeb, Z. Elnasser, O. Rasslan, D. Gür, Z. Daoud, and D. P. Bagatzouni. 2009. "Health Care Worker Perceptions of Hand Hygiene Practices and Obstacles in a Developing Region." American Journal of Infection Control 37 (10): 855-7. https://doi.org/10.1016/j.ajic.2009.06.003.

Boyce, J. M., P. M. Polgreen, M. Monsalve, D. R. Macinga, and J. W. Arbogast. 2017. "Frequency of Use of Alcohol-Based Hand Rubs by Nurses: A Systematic Review." Infection Control and Hospital Epidemiology 38 (2): 189-195. https://doi.org/10.1017/ice.2016.247.

Brown, T. L., S. Gamon, P. Tester, R. Martin, K. Hosking, G. C. Bowkett, D. Gerostamoulos, and M. L. Garyson. 2007. "Can Alcohol-Based Hand-Rub Solutions Cause You to Lose Your Driver's License? Comparative Cutaneous Absorption of Various Alcohols." Antimicrobial Agents and Chemotherapy 51 (3): 1107-1108. https://doi.org/10.1128/AAC.01320-06.

Chavali, S., V. Menon, and U. Shukla. 2014. "Hand Hygiene Compliance among Healthcare Workers in an Accredited Tertiary Care Hospital." Indian Journal of Critical Care Medicine 18 (10): 689-693. https://doi.org/10.4103/0972-5229.142179.

Darawad, M. W., M. Al-Hussami, I. I. Almhairat, and M. Al-Sutari. 2012. "Investigating Jordanian Nurses' Handwashing Beliefs, Attitudes, and Compliance." American Journal of Infection Control 40 (7): 643-7. https://doi.org/10.1016/j.ajic.2011.08.018. 
Askarian, Shiraly, Longtin, Seyed Nematian

Doronia, O., D. Jones, M. Martello, A. Biron, and M. Lavoie-Tremblay. 2017. "A Systematic Review on the Effectiveness of Interventions to Improve Hand Hygiene Compliance of Nurses in the Hospital Setting.” Journal of Nursing Scholarship 49 (2): 143-152. https://doi.org/10.1111/jnu.12274.

Erasmus, V., T. J. Daha, H. Brug, J. H. Richardus, M. D. Behrendt, M. C. Vos, and E. F. van Beeck. 2010. "Systematic Review of Studies on Compliance with Hand Hygiene Guidelines in Hospital Care.” Infection Control and Hospital Epidemiology 31 (3): 28394. https://doi.org/10.1086/650451.

Gessner, S., E. Below, S. Diedrich, C. Wegner, W. Gessner, T. Kohlmann, C. D. Heidecke, B. Bockholdt, A. Kramer, O. Assadian, and H. Below. 2016. "Ethanol and Ethyl Glucuronide Urine Concentrations after Ethanol-based Hand Antisepsis with and without permitted Alcohol Consumption.” American Journal of Infection Control 44 (9): 999-1003. https://doi.org/10.1016/j.ajic.2016.02.021.

Girou, E., S. Loyeau, P. Legrand, F. Oppein, and C. Brun-Buisson. 2002. "Efficacy of Handrubbing with Alcohol-based Solution versus Standard Handwashing with Antiseptic Soap: Randomised Clinical Trial.” British Medical Journal 325 (7360): 362. https://doi.org/10.1136/bmj.325.7360.362.

Kampf, G., and A. Kramer. 2004. "Epidemiologic Background of Hand Hygiene and Evaluation of the Most Important Agents for Scrubs and Rubs." Clinical Microbiology Reviews 17 (4): 863-893. https://doi.org/10.1128/CMR.17.4.863-893.2004.

Kampf, G., and H. Löffler. 2007. "Prevention of Irritant Contact Dermatitis among Health Care Workers by using Evidence-based Hand Hygiene Practices: A Review.” Industrial Health 45 (5): 645-52. https://doi.org/10.2486/indhealth.45.645.

Kingston, L. M., B. L. Slevin, N. H. O’Connell, and C. P. Dunne. 2017. "Hand Hygiene: Attitudes and Practices of Nurses, A Comparison between 2007 and 2015." American Journal of Infection Control 45 (12): 1300-1307. https://doi.org/10.1016/j.ajic.2017.08.040.

Kingston, L. M., N. H. O’Connell, and C. P. Dunne. 2018. "A Comparative Study of Hand Hygiene and Alcohol-based Hand Rub Use among Irish Nursing and Medical Students." Nurse Education Today 63: 112-118. https://doi.org/10.1016/j.nedt.2018.01.022.

Lachenmeier, D. W. 2008. "Safety Evaluation of Topical Applications of Ethanol on the Skin and inside the Oral Cavity." Journal of Occupational Medicine and Toxicology 3: 26. https://doi.org/10.1186/1745-6673-3-26.

Li, Y., Y. Wang, D. Yan, and C. Y. Rao. 2015. "Self-reported Hand Hygiene Practices and Feasibility and Acceptability of Alcohol-based Hand Rubs among Village Healthcare Workers in Inner Mongolia, China." Journal of Hospital Infection 90 (4): 338-43. https://doi.org/10.1016/j.jhin.2015.04.006. 
Askarian, Shiraly, Longtin, Seyed Nematian

Longtin, Y., H. Sax, B. Allegranzi, F. Schneider, and D. Pittet. 2011. "Hand Hygiene.” New England Journal of Medicine 364 (13): e24. https://doi.org/10.1056/NEJMvcm0903599.

Michalak, L., K. Trocki, and K. Katz. 2009. "I am a Muslim and My Dad is an Alcoholic: What Should I Do?": Internet-based Advice for Muslims about Alcohol. Journal of Muslim Mental Health 4 (1): 47-66. https://doi.org/10.1080/15564900902771325.

Ng, W. K., R. Z. Shaban, and T. van de Mortel. 2019. "The Effect of a Hand Hygiene Program Featuring Tailored Religion-relevant Interventions on Healthcare Workers' Hand Rubbing Compliance and Beliefs in the United Arab Emirates: A Cohort Study." Infection, Disease and Health 24 (3): 115-123. https://doi.org/10.1016/j.idh.2019.01.002.

Picheansathian, W. 2004. "Effectiveness of Alcohol-based Solutions for Hand Hygiene: A Systematic Review." JBI Library of Systematic Reviews 2 (9): 1-27. https://doi.org/10.11124/jbisrir-2004-375.

Pittet, D. 2009. "Religious and Cultural Aspects of Hand Hygiene. WHO Guidelines on Hand Hygiene in Health Care: First Global Patient Safety Challenge Clean Care Is Safer Care." Geneva: World Health Organisation. Accessed January 2, 2021. https://www.who.int/gpsc/5may/tools/who_guidelines-handhygiene_summary.pdf.

Randle, J., A. Arthur, N. Vaughan, H. Wharrad, and R. Windle. 2014. "An Observational Study of Hand Hygiene Adherence Following the Introduction of an Education Intervention." Journal of Infection Prevention 15 (4): 142-147. https://doi.org/10.11124/01938924-200402090-00001.

Reichardt, C., D. Königer, K. Bunte-Schönberger, P. van der Linden, N. Mönch, F. Schwab, M. Benke, and P. Gastmeier. 2013. "Three Years of National Hand Hygiene Campaign in Germany: What Are the Key Conclusions for Clinical Practice?" Journal of Hospital Infection, Suppl 1: S11-S16. https://doi.org/10.1016/S0195-6701(13)60004-3.

Sands, M., and R. Aunger. 2020. "Determinants of Hand Hygiene Compliance among Nurses in US Hospitals: A Formative Research Study." PLOS ONE 15 (4): e0230573. https://doi.org/10.1371/journal.pone.0230573.

Sharma, M., R. Joschi, R. Macaden, and C. S. Lundborg. 2015. 'A Step-wise Approach towards Introduction of an Alcohol-based Hand Rub, and Implementation of Front Line Ownership: Using a, Rural, Tertiary Care Hospital in Central India as a Model." BMC Health Services Research 15: 182. https://doi.org/10.1186/s12913-015-0840-1.

Takra, P., K. Gutkowska, and A. Nitsch-Osuch. 2019. “Assessment of Tolerability and Acceptability of an Alcohol-based Hand Rub according to a WHO Protocol and using Apparatus Tests. Antimicrobial Resistance and Infection Control 8: 191. https://doi.org/10.1186/s13756-019-0646-8. 
Askarian, Shiraly, Longtin, Seyed Nematian

Von Lengerke, T., B. Lutze, C. Krauth, K. Lange, J. T. Stahmeyer, and I. F. Chaberny. 2017. "Promoting Hand Hygiene Compliance." Deutsches Arzteblatt International 114 (3): 2936. https://doi.org/10.3238/arztebl.2017.0029.

World Health Organisation. 2009. "Save Lives Clean your Hands Guide to Implementation. A Guide to the Implementation of the WHO Multimodal Hand Hygiene Improvement Strategy". Geneva: WHO/IER/PSP/2009.02. Accessed January 2, 2021. https://www.who.int/gpsc/5may/Guide_to_Implementation.pdf. 